
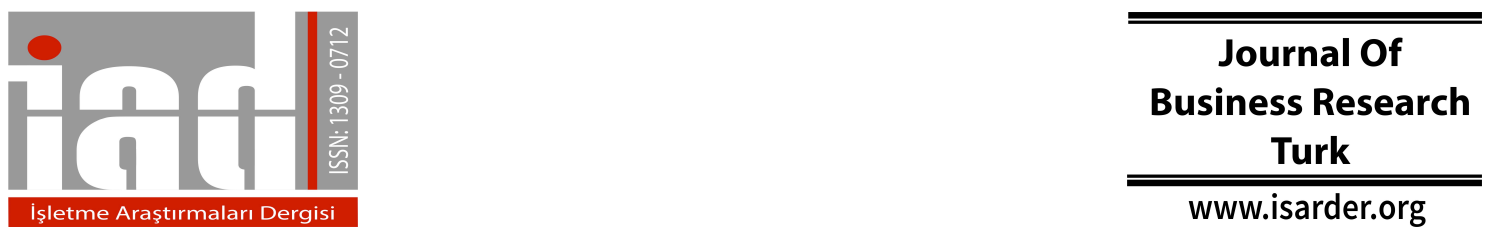

\title{
The Moderating Role of Job Satisfaction on the Relationship between Servant Leadership and Turnover Intention
}

\author{
Hakan TURGUT \\ Baskent University \\ Vocational School of Social \\ Sciences \\ Ankara, Turkey \\ hturgut@,baskent.edu.tr
}

\author{
Mustafa BEKMEZCI \\ National Defense \\ Ministry, \\ Management and Strategy \\ Ankara, Turkey \\ mbekmezci1@gmail.com
}

\author{
M. Fikret ATEŞ \\ Baskent University \\ Vocational School of Social \\ Sciences \\ Ankara, Turkey \\ mfates@baskent.edu.tr
}

\begin{abstract}
One of the aims of this study is to determine how the servant leadership will affect turnover intention and job satisfaction in tourism sector. Another aim is to discover whether job satisfaction has an indirect effect on the relationship between servant leadership and turnover intention. The data used in this study is gathered through survey in November 2016, from 191 participants employed in accommodation facilities in Belek-Antalya. Cronbach's Alpha coefficients of the scales used in the survey are calculated and they are proved to be rather reliable for this sample. The results of regression analyses show that there is a positive relationship between servant leadership and job satisfaction however there is a negative relationship between servant leadership and turnover intention. There is a negative relationship between job satisfaction and turnover intention and there is a partial moderating role of job satisfaction on the relationship between servant leadership and turnover intention.
\end{abstract}

Keywords: Job satisfaction, servant leadership, turnover intention

\section{Introduction}

At the end of 1950s the literature of organizational behavior recognized how important it is for the employees to be 'humanistic' as well as being intellectual, talented and hardworking (Kostera, \& Pirson, 2017). Many recent studies on this subject showed that the satisfaction of internal and external stakeholders and the maintenance of this happiness are accepted as quite significant periods (Fonseca et al., 2016). Apart from that, employees with the role of internal stakeholders, which is the most important force in sustainable competition, integrating with their organizations and maintaining their interests towards their jobs and workplaces is believed to be related to the fulfillment of their expectations (Purvisa, Zagenczykb, \& McCrayc, 2015).

In maintaining the qualified workforce within the organization which is the indispensable element of sustainable competition, the crucial assistant of the managements is the maintenance of the peace and welfare of the employees (Arekar, Jain, Desphande, \& Sherin, 2016). Job satisfaction emerges when the employees are 
motivated, successful and productive with the efforts of the organization (Judge et al., 2017), and dissatisfaction emerges when turnover intention, the consequence of exhaustion, absenteeism and resignation is observed (Mowday, Porter, \& Steers, 2013). For the solution of major problems such as the leaders' knowing the characteristics and how to behave, the approach of servant leadership, which provides its followers with opportunities of achievement, contributing to their solutions and giving priority to their development, is assumed to be effective.

Job satisfaction, which is related to the fulfillment of the expectations of employees (Judge, \& Locke, 1993; Ishfaq et al., 2011) has been attracting attention for a long time in terms of the fields of psychology and behavioral sciences (Yang \& Wang, 2013) by displaying respect that the employees deserve through humanistic approach (Callaghan, \& Coldwell, 2014). Furthermore, the theory of affective events developed by Howard M. Weiss and Russell Cropanzano (1996), was used to explain how emotions and moods affect job performance and job satisfaction (Thompson, \& Phua, 2012). As job satisfaction has a multi - dimensional structure one of its two different definitions is the positive emotions about the employee's job that are formed when he evaluates the characteristics of his job (leadership, management style, promotion opportunities, working conditions and human relations) (Robbins \& Judge, 2012). Job satisfaction is also defined as the response to employees' acquirements within the organization (wage, other benefits, appreciation, promotion) (Gordon, 2011). Both definitions show that job satisfaction is a group of emotions that keep changing from negative to positive or from positive to negative (Mowday, Porter, \& Steers, 2013).

Employee policies which are able to choose the right from wrong, meet the stakeholders' expectations and present development opportunities are expected to clear the way for achievements (Fonseca et al., 2016). However, it is also observed that in the display of attitudes and manners that are compatible to organizational targets, the fulfillment of only the material and immaterial expectations is not enough for the employees (Bianchi, 2013). For this reason, the employees should be encouraged and supported in order to contribute to the organization as much as they can and the importance of 'leaders' who can take responsibility and the notion of 'leadership' should be emphasized (Johnson, 2015). In the studies done on these subjects, several models on leadership have been presented and different aspects of these models have been discussed (Metcalf \& Benn, 2012).

Greenleaf $(1970,1972,1977)$, one of these models, has been attracting the attention of the researchers especially recently, taking place in literature about leadership with the writings on Servant Leadership (Russell \& Stone, 2002; Dennis \& Winston, 2003; Dutta, \& Khatri, 2017). Although the concepts of 'leader' and 'servant' being used in the same definition was considered as contradictory at the beginning (Yoshida, Sendjaya, Hirst, \& Cooper, 2014), servant leadership, which was examined commonly in terms of characteristics and normative principles, was accepted as a conception of leadership with heuristic and practical values (Northouse, 2014). Greenleaf's explanation of servant leadership approach with religious events; such as Jesus Christ's doctrines (Sendjaya \& Sarros, 2002: 58) and the servant character in Herman Hesse's novel "The Journey to the East" was effective rather than explaining it by scientific data. According to Greenleaf, servant leadership, who is "eager to serve rather than leading the way" (1970: 15) start by serving which is a natural thought for 
people and forward them to leading as a conscious choice (Russell, 2001; Dennis \& Winston, 2003; Vinod \& Sudhakar, 2011).

Servant leadership approach expresses not only a management method but also a lifestyle (Parris \& Peachey, 2013) and it keeps the welfare and benefit of the leaders' followers above their own benefits and gives importance to their development (Northouse, 2014). Greenleaf $(1970,1972,1977)$ listed the 10 features of servant leadership in his writings as 'listening, empathy, healing, awareness, persuasion, conceptualization, foresight, taking responsibility for the role of leadership (stewardship), commitment to the growth of people and focusing on the development of a community (building community) (Spears, 2010).

In the recent years, the researchers who study the conceptual elements that support servant leadership in order to form a theory, have used several variables and as a result, presented different models (Farling et al., 1999; Laub, 1999; Page \& Wong, 2000; Sendjaya \& Sarros, 2002; Russell \& Stone, 2002; Dennis \& Winston, 2003; Dennis \& Bocarnea, 2005; Barbuto \& Wheeler, 2006; Wong \& Davey, 2007; Sendjaya et al., 2008; Liden et al., 2008; Reed et al., 2011). Nevertheless all these studies show that there is not an agreement among the researchers as servant leadership is considered as a personal characteristic (reliability, modesty, etc.) in some studies; it is considered as a behavioral and relational process (serving and improving others, etc.) in other studies and positive attitude, behavioral and personal characteristics are usually evaluated within the concept of servant leadership (Spears, \& Lawrence, 2002, Dutta, \& Khatri, 2017).

As mentioned above, certain changes in the lives of personal and professional lives of employees cause both personal and organizational processes to be affected by each other. During this process while the positive changes in the perceptions of motivation, success and satisfaction increase organizational loyalty, one or more of these items being in a low level may cause the person to display negative attitude and behavior. At this point, as leader and leadership styles form a bridge between the organization and the employee, their effect on job satisfaction is inevitable. With this information it could be foreseen that taking the necessary precautions to prevent the employees from resigning is an important mission of the leaders.

Turnover intention, which is defined as the employee's conscious intention of leaving the organization (Kalidass, \& Bahron 2015), are employee's ideas that he hasn't put into action yet and this stage is a decision making process (Wang, Tsai, Lei, \& Lai, 2016). Forms of turnover intention are leaving the job although there are no other job opportunities or leaving the job because there are other job opportunities (Mowday, Porter, \& Steers, 2013). Employees may not be satisfied with the working conditions even though there are no new job opportunities; in this case, turnover intention is considered as both cognitive and behavioral since it may result in both passive attitude (ignoring your job) and active attitude (leaving the job) towards the organization (Sam Gnanakkan, 2010).

In the light of these definitions and explanations, turnover intention is affected by several factors such as individual factors (education, family, retirement, health conditions, death, marriage, etc.), organizational factors (wage, working conditions, career, lack of communication, management, etc.) and environmental factors (war, economy, government) (Kreitner, \& Kinicki, 2012). As a result of turnover intention, 
the decision of resignation affects organizational effectiveness negatively and it increases management costs. Resignation of employees causes serious problems in terms of gaining superiority in competition due to issues such as losing talented employees, choosing new employees and training and orienting these employees (Jha, 2014).

\section{Relations among Variables}

The reason why several people like working is the job they do is meaningful and it requires their knowledge and intellect (Diestel, Wegge, \& Schmidt, 2014). Therefore it is an undeniable fact that people perform positive attitude in satisfying and pleasing situations. In this respect, the importance of the studies done on Job satisfaction and turnover intention is mentioned above (Yang \& Wang, 2013). Job satisfaction affects several individual behaviors within the organization such as high achievement, joining an organization and remaining in that organization, low absenteeism and low turnover rate (Mc Shane \& Von Glinow, 2016).

Job satisfaction affects not only the individual but also the organization directly and it leads to non - ignorable results. Thus, in a study, the organizations were separated as ones that have high job satisfaction perception (more than 70\%) and ones that have low job satisfaction perception (less than 70\%) and it was determined that the stock prices of the organizations with high job satisfaction perception rose a rate of $19.4 \%$ and the stock prices of the organizations with low job satisfaction perception rose a rate of $10 \%$ (Robins \& Judge, 2012).

In organizational environment, leaders affect the attitudes and behaviors of the employees towards their organizations directly with their personality, decisions and their implementations (Shipton, Sanders, Atkinson, \& Frenkel, 2016). Therefore, that management styles and participation facilities as well as leadership style are effective in preventing turnover intention and increasing job satisfaction is an undeniable fact (Wang et al., 2016). The presence of leaders who possess a natural desire to serve others, give priority to the development of his followers and are sensitive will increase the employees' job satisfaction and decrease turnover intention (Parris \& Peachey, 2013).

The consequences of some studies done on job satisfaction (Mc Shane \& Von Glinow, 2016) are as follows: There is a partly positive relationship between job satisfaction and performance. In other words, when employees have positive attitude towards their jobs and organizations, they are more productive to a certain extent (Ihm, et al., 2014). In addition, it is stated that employees who are pleased with their jobs and workplaces have positive emotions and this is reflected on their behavior and it also increases customer satisfaction. The findings of the empirical study in literature confirm that job satisfaction is usually based on the premise of the organizational loyalty of the employees (Tarigan, \& Ariani, 2015).

Job satisfaction, which is defined as a pleasant or emotional situation resulting from an individual's experiences at his workplace or his experiences related to his work (Lan, Okechuku, Zhang, \& Cao, 2013) depends on many organizational and individual factors and it is also an important issue in preventing turnover intention. In literature it is mentioned that job satisfaction is negatively related to turnover intention, when there is dissatisfaction turnover intention will increase and therefore motivation, effectiveness 
and achievement will decrease (Gunlu, Aksarayli, \& Percin, 2010). Nevertheless, a negative relationship was found between job satisfaction and turnover intention (Tarigan, \& Ariani, 2015).

The studies show that servant leadership has strong effects on job satisfaction, which has certain positive effects on individual and organizational output (Anderson, 2005; Cerit, 2009; Dennis, Kinzler - Norheim \& Bocarnea, 2010; Yang \& Wang 2013). As a result of a comprehensive literature study, it was found out that servant leadership increases trust in the leader (Sendjaya \& Pekerti, 2010), organizational citizenship behavior (Vondey, 2010), team and leader effectiveness (Irving \& Longbotham, 2007), cooperation (Joseph \& Winston, 2005), job satisfaction (Cerit, 2009), creativity (Yoshida et al., 2014), cooperation behavior (Stone, Russell \& Patterson, 2004) and organizational loyalty (Kool \& Van Dierendonck, 2012) and it decreases turnover intention (Jaramillo, Grisaffe, Chonko \& Roberts, 2009); moreover, it has a positive relationship with the perception of organizational justice and organizational atmosphere (Walumbwa, Hartnell \& Oke, 2010; Parris \& Peachey, 2013).

As it could be understood from these data, what managers do to keep the present talents at hand concerning human relations are of utmost importance. Determining the factors that affect the intention of resignation is crucial in foreseeing the behavior of employees' resignation and taking the necessary precautions about it (Boswell, Gardner, \& Wang, 2017). In this respect, some of the precautions to decrease the resignation intentions of the employees and increase their loyalty to the organization might be increasing the motivation, providing opportunities of growth and development and building a proper rewarding system.

\section{Methodology}

\subsection{Empirical Model and Hypotheses}

In literature study, although Servant Leadership is tried to be explained by its five dimensions, there are a lot of studies about it on how it affects job satisfaction and turnover intention. And in this study, inspired by the previous studies, the relations between five - dimension servant leadership, job satisfaction and turnover intention are studied and hypotheses questioning whether job satisfaction has an indirect effect in these relations and the research model are presented in Figure 1.

Figure 1: Research Model

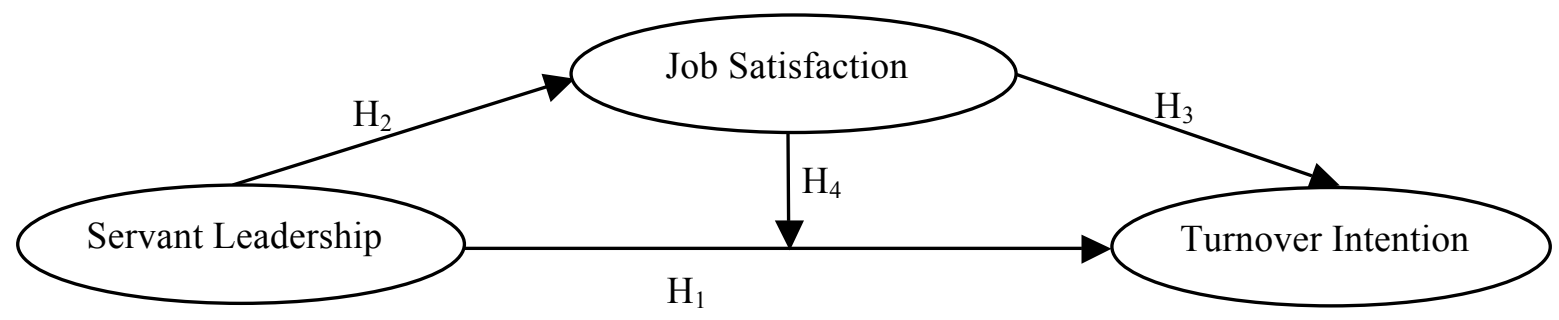

Hypothesis 1: Servant leadership has got a significant and positive effect on turnover intention

Hypothesis 2: Servant leadership has got a significant and positive effect on job satisfaction 
Hypothesis 3: Job satisfaction has got a significant and negative effect on turnover intention

Hypothesis 4: Job satisfaction has got an indirect effect on the relationship between servant leadership and turnover intention.

\subsection{Sample}

There are a total of 47 hotels located in Belek, Antalya, which are five-star accommodation organizations and are members of Belek Tourism Investors Joint Venture. However, the population of this study consists of 9.200 employees employed in 23 golf resorts hotels where world golf tournaments take place and which are famous worldwide. In a finite population, when the original sample collected is more than 5\% of the population size, the corrected sample size is determined by using the Yamane (1967)'s formula is given by:

$$
\mathrm{N}=\frac{\mathrm{N}}{1+\mathrm{N} *(\mathrm{e})^{2}}
$$

$n=$ sample size,

$N=$ population size,

$e=0.05$ the acceptable sampling error

*95\% confidence level and $p=0.5$ are assumed

The population of this study is 9.200 using $95 \%$ confidence interval. The sample size were calculated 384 for this population size by using Yamane (1967)'s formula.

In the process of gathering the survey data, the managers of 23 golf resorts were called and they were asked to encourage their staff to contribute to the research. 500 surveys were sent to the employees determined by the managers who agreed to contribute to this study by e-mail. 257 of the surveys were sent back; however, 66 surveys were not evaluated as the participants were not able to complete more than $10 \%$ of the survey questions. The surveys of 191 participants who coded the answers correctly are evaluated.

One of the reasons why this population is chosen is that Belek, Antalya is considered as a significant region and it is known to have an important potential for Turkish Tourism Sector (Bolat et al., 2009). Another reason is that the management structures of these golf resorts whose customers are conscious and have a high income and cultural level, are more corporate and innovative compared to other hotels. Besides, such hotels possess modern and professional management and organization systems within their structures (Pelit, 2011) and the employees employed in these organizations have a high level of education.

As employees in golf tourism sector have a heavy workload from September to November (2016) (Bolat et al., 2009), the whole population was not available in terms of time and place; therefore, convenience sampling method, which is one of the non-probability sampling methods, is preferred.

In this study, $37.9 \%$ of the participants are female and $62.8 \%$ of them are male. $47.6 \%$ of them are married and $52.4 \%$ of them are single. The average age is 29.41 ( $\mathrm{ss}=6.78$ ). Regarding the participants' educational status; $53.1 \%$ of them have high school, $9.4 \%$ have associate education and $2.6 \%$ have license and $0.5 \%$ have master degrees. $6.3 \%$ of them are managers, $93.7 \%$ of them are employees. $3.1 \%$ of them work in head office, 
$29.6 \%$ of them work in food \& beverage, $44,5 \%$ work in housekeeping, $9.3 \%$ work in front office, $13.5 \%$ work in marketing $\&$ sales. The average tenure of the participants is $5.84(\mathrm{ss}=6.07)$ their tenure in this current workplace is as follows: $53.92 \%$ of them had been working for a year, $19.18 \%$ of them for $2-5$ years, $20.41 \%$ of them for $6-10$ years, 3.66 of them $11-15$ years and $2.09 \%$ of them for 15 years and more.

\subsection{Measures}

Job Satisfaction Scale; to measure the job satisfaction perceptions of the employees, the 5 item scale prepared by Chen and his friends (2009) by giving reference to Arnett (1999) and Judge and friends (2009) is used. The Turkish adaptation of the job satisfaction scale was done by Turunç and Çelik (2012). The scale consists of 5 statements such as "I feel satisfied with my job" and "when I'm doing my job I feel like the day is never going to end". The measurements were done by 5 Likert Type Scale. And the single factor structure of the scale was confirmed as the results are parallel to the ones that were gathered in the study of Turunç and Çelik (2012). The Cronbach's Alpha Coefficient calculated for the scale in general is 0.86 . The results gathered by the analyses show that job satisfaction scale is valid and reliable for this sample group.

Turnover Intention Scale; to measure the turnover intention of the participants, the 4 - item scale, which was developed by Scott and his friends (1999) and adapted into Turkish by Aylan (2012) is used. The scale consists of four statements, one of which consists of reverse wording; such as "I'm thinking of working here until I retire" and "I'm thinking of looking for a job next year". The measurements were done by 5 Likert Type Scale. And the single factor structure of the scale was confirmed as the results are parallel to the ones that were gathered in the study of Aylan (2012). The Cronbach's Alpha coefficient calculated for the scale in general is 0.82 . The results gathered by the analyses show that turnover intention scale is valid and reliable for this sample group.

Servant Leadership Scale which was developed by Dennis and Bocernea (2006) and adapted into Turkish by Aslan and Özata (2006) consists of 14 questions and 5 factors. The dimension of affection is measured by three $(1-3)$, the dimension of empowerment is measured by three ( $4-6)$, the dimension of vision is measured by three ( 7 - 9), the dimension of sacrifice is measured by two $(10-11)$ and the dimension of trust is measured by three $(12-14)$ statements. The scale is a 5 Likert Type Scale. $(1=$ Never, $3=$ Sometimes, $5=$ Always). According to the reliability analysis of Aslan and Özata (2006) the Cronbach's Alpha Coefficient $(\alpha)$ is calculated as 0.97 and the scale is found very reliable.

\subsubsection{The validity and Reliability of the Scales}

To test the validity of the scales that are used in the study, a second order confirmatory factor analysis for the variable servant leadership and a single factor confirmatory factor analysis for the variables job satisfaction and turnover intention were done. As a result of the factor analyses which were done to determine the validity of the scales, a single factor result for job satisfaction and turnover intention and a five factor result for servant leadership was collected, in accordance with the literature.

\subsection{Findings}

The averages, standard deviations and correlation values are shown in Table 2. As a result of the analyses, there is a positive and significant relationship between servant 
leadership and job satisfaction in medium level $(\mathrm{r}=.40 ; \mathrm{p}<.01)$, there is a negative and significant relationship between servant leadership and turnover intention in medium level $(\mathrm{r}=-.45 ; \mathrm{p}<.01)$, and there is a negative and significant relationship between job satisfaction and turnover intention in medium level $(\mathrm{r}=-.49 ; \mathrm{p}<.01)$.

Table 2: The Average, Standard Deviation and Correlation Values $(n=191)$

\begin{tabular}{lccccc}
\hline \multicolumn{1}{c}{ Variables } & Mean & sd & $\mathbf{1}$ & $\mathbf{2}$ & $\boldsymbol{\alpha}$ \\
\hline Servant Leadership (SL) & 2.86 & 1.02 & & & .87 \\
\hline Job Satisfaction (JS) & 3.19 & .83 & $.404^{* *}$ & & .86 \\
\hline Turnover Intention (TOI) & 2.95 & 1.07 & $-.453^{* *}$ & $-.487^{* *}$ & .95 \\
\hline
\end{tabular}

$* * \mathrm{p}<.01 ; * \mathrm{p}<.05$

The reliability of the scales was tested by calculating their Cronbach's Alpha Coefficients $(\alpha)$ and the scales were found to be quite reliable. The adaptive values of the scales are presented in Table 3.

Table 3: The Adaptive Values of the Scales

\begin{tabular}{lcccccc}
\hline \multicolumn{1}{c}{ Scales } & $\mathbf{X}^{\mathbf{2}}$ & $\mathbf{d f}$ & $\mathbf{X}^{\mathbf{2}} \mathbf{d f}$ & GFI & CFI & RMSEA \\
\hline Job Satisfaction * & 18.72 & 5 & 3.74 & .962 & .969 & .120 \\
Turnover Intention ** & 1.31 & 2 & .65 & .997 & 1.0 & .0 \\
Servant Leadership *** & 165.46 & 67 & 2.46 & .888 & .982 & .088 \\
\hline Well Adaptive Values * & & & $\leq 3$ & $\geq .90$ & $\geq .97$ & $\leq .05$ \\
\hline Acceptable Adaptive Values * & & $\leq 4-5$ & $.89-.85$ & $\geq .95$ & $.06-.08$ \\
\hline$* \mathrm{p}=.00217, * * \mathrm{p}=.519, * * * \mathrm{p}=.00, \mathrm{p}>.05$ & & & & &
\end{tabular}

According to these results, it could be foreseen that there might be a significant and crucial effect among variables. In the scope of data analysis, it was checked whether multicollinearity exists or not. The Tolerance and VIF values confirmed that there is no multicollinearity among the independent variables (Tolerance $>.2 ; \operatorname{VIF}<10$ ).

\subsubsection{Findings Related to Regression Analyses}

In the second step of the analysis, the indirect effect of job satisfaction in the relationship of servant leadership between turnover intention is examined. The indirect effect is the changing of the relationship between two variables on different levels of a third variable. The indirect variable is defined as a third variable which affects the direction or the strength of the relationship between the dependent and the independent variables (Baron \& Kenny, 1986). To analyze the indirect effect, the indirect variable should be multiplied with the independent variable and the result obtained should be the interaction variable. If this interaction variable is significant there might be an indirect effect (Baron \& Kenny, 1986).

The data in Table 4 show that the relationship between servant leadership and turnover intention is significant and negative $(\beta=-.453 ; \mathrm{p}<.01)$; therefore Hypothesis 1 is accepted. 
H. Turgut - M. Bekmezci - M.F. Ateş 9/2 (2017) 300-314

Table 4: Regression Analyses Results ( $N=191)$

\begin{tabular}{|c|c|c|c|c|c|c|}
\hline \multirow{2}{*}{ Steps } & \multirow{2}{*}{$\begin{array}{c}\text { Independent } \\
\text { Variable }\end{array}$} & \multirow{2}{*}{$\begin{array}{c}\text { Dependent } \\
\text { Variable }\end{array}$} & \multicolumn{3}{|c|}{ Regression Coefficients } & \multirow{2}{*}{ Model Statistics } \\
\hline & & & $\mathbf{B}$ & S.H. & $\beta$ & \\
\hline Step 1 & SL & TOI & -.478 & .068 & $-.453 * *$ & $\begin{aligned} \mathrm{R}^{2} & =.205 \\
\mathrm{~F}_{(1.189)} & =48.737\end{aligned}$ \\
\hline Step 2 & SL & JS & .329 & .054 & $.404 * *$ & $\begin{aligned} \mathrm{R}^{2} & =.163 \\
\mathrm{~F}_{(1.189)} & =36.800\end{aligned}$ \\
\hline Step 3 & JS & TOI & -.630 & .082 & $-.487 * *$ & $\begin{array}{c}\mathrm{R}^{2}=.237 \\
\mathrm{~F}_{(1.189)}=58.802\end{array}$ \\
\hline Step 4 & $\begin{array}{l}\text { SL } \\
\text { JS }\end{array}$ & TOI & $\begin{array}{l}-.323 \\
-.470\end{array}$ & $\begin{array}{l}.070 \\
.085\end{array}$ & $\begin{array}{l}-.306 * * \\
-.364 * *\end{array}$ & $\begin{aligned} \mathrm{R}^{2} & =.316 \\
\mathrm{~F}_{(2.188)} & =43.359\end{aligned}$ \\
\hline
\end{tabular}

As servant leadership has a significant and positive effect on job satisfaction $(\beta=$ $.404 ; \mathrm{p}<.01)$, Hypothesis 2 is accepted as well. In addition, job satisfaction has a significant and negative effect on turnover intention $(\beta=-.487 ; p<.01)$, and therefore, Hypothesis 3 is accepted. Regarding the effects of servant leadership and job satisfaction on turnover intention, it is determined that servant leadership has a significant and negative effect on turnover intention $(\beta=-.306 ; p<.01)$ and job satisfaction has a significant and negative effect on turnover intention $(\beta=-.364 ; \mathrm{p}<$ $.01)$ as well.

To be able to mention the indirect effect, when all the independent and indirect variables are included in the model, the existence of the indirect variable should lose or lower its significant effect of the independent variable on the dependent variable. In this respect, the findings above show that job satisfaction decreases the effect level between servant leadership and turnover intention. And this proves that job satisfaction has a partial indirect effect between servant leadership and turnover intention.

However, this decrease is not enough to mention about the indirect effect. To confirm the indirect effect, a SOBEL Test was done and the calculations show that the indirect effect is statistically significant $(z=-4.77376 ; p<.01)$. This finding proves that job satisfaction has an indirect effect between servant leadership and turnover intention so Hypothesis 4 is also accepted.

\section{Conclusions}

In the literature of organizational behavior, the researchers and leading theoreticians have been trying hard to present the approach of servant leadership and help it become a common leadership style for the present organizations. Apparently as the servant leadership approach becomes popular; it will be inevitable for the individuals and the organizations to go through certain changes. Servant leadership approach is expected to bring a lot of small but powerful innovations in people's private and professional lives. This leadership approach which can be explained very well theoretically, has not been supported by experimental researches; this has contributed to the formation of this study.

In this study the results gained in relationships between servant leadership and job satisfaction or servant leadership and turnover intention are parallel to the findings with the previous studies (Lok \& Crawford, 2004; Karsh et al., 2005; Randhawa, 2007; Yang \& Wang, 2013; Mc Shane \& Von Glinow, 2016). These findings prove that leaders, 
who perform high servant leadership in the relationships with their followers, not only contribute to their organizations but also improve job satisfaction and decrease turnover intention.

In literature there are many studies about Job satisfaction increasing organizational loyalty and therefore decreasing turnover intention, which is the primary cause of resignation. The reason why job satisfaction is found worth studying and being emphasized is that it has many positive effects on organizational output. Job satisfaction not only depends on the personality of the employee, his perceptions of job specifications, his working environment and his emotional experiences in the workplace but also the leadership style of the managers.

In other words, job specifications and physical and social conditions of the working environment are as essential for job satisfaction as the behaviors of the leader who is going to provide the employees with these conditions. To sum up, leaders' paying attention to the needs of the employees, taking care of them individually and helping them develop and improve themselves personally; in short, displaying an employee - based attitude is going to affect the attitudes of the employees towards their jobs and workplaces positively.

As a result of this study, it has been determined that there is a negative and significant relationship between servant leadership, which focuses on the followers and the behavior that gives priority to their personal development and turnover intention; in addition, it has also been determined that there is a negative and significant relationship between job satisfaction and turnover intention. As a consequence, both servant leadership behavior and job satisfaction have dramatic effects on turnover intention. In other words, job satisfaction helps us explain the effects of servant leadership behavior on turnover intention.

This study aimed to find out which leadership approach is more appropriate in increasing the success of the employees who are employed in 5 - star accommodation organizations, which are members of BEINJOV - (Belek Tourism Investors Joint Venture) in Antalya - Belek in Turkey. Furthermore, it focuses on improving the leader - follower relationship; helping more leaders realize the benefits of using the servant leadership approach in improving their relationship with their leaders, helping to affect the professional behaviors of the employees positively and increasing the job satisfaction of the followers.

This study also aims to help the organizations and institutions which give leadership training by helping them train their participants properly. For instance, it brings out the idea of giving a servant leadership training to help the leaders, who will improve the organizational loyalty of the employees, to develop their leadership skills.

In addition, as there are few empirical studies on servant leadership in the developing countries such as Turkey, this study is expected to lead the way to future studies similar to this one or the ones in other fields. However, when the study was done, the time being limited in seasonal terms and the sample group consisting of employees who are employed in accommodation organizations only could be mentioned as the limitations of the study. Repeating the study in different sectors and sample groups and making a larger evaluation for the gathered results could be suggested. 


\section{References}

Anderson, K. P. (2005). A correlational analysis of servant leadership and job satisfaction in a religious educational organization (Unpublished Doctoral Dissertation), University of Phoenix.

Arekar, K., Jain, R., Desphande, B., \& Sherin, P. (2016). Relationship between individual and structural determinants on job satisfaction-analysis of employee turnover in the Indian context. The Journal of Developing Areas, 50 (6), 387 398.

Arnett, J. J. (1999). Adolescent storm and stress, revisited, American Psychologist, 54 (5), 317 - 326.

Aslan, Ş., \& Özata, M. (2011). Servant leadership among medical staff: Investigation of validity and reliability of Dennis - Winston and Dennis - Bocernea servant leadership scales., Journal of Management \& Economics, 18 (1), 139 - 154

Aylan, S., (2012). A case of determining the relationships between mobbing in lodging organizastions and employees' intention to leave, (Unpublished Master's Dissertation), Gazi Universitesi Institute of Educational Sciences, Ankara.

Barbuto Jr, J. E., \& Wheeler, D. W. (2006). Scale development and construct clarification of servant leadership. Group \& Organization Management, 31 (3), $300-326$.

Baron, R. M. \& Kenny, D. A. (1986). The moderator mediator variable distinction in social psychological research: Conceptual, strategic, and statistical considerations, Journal of Personality and Social Psychology, 51, 1173 - 1182.

Bianchi, E. C. (2013). The bright side of bad times: The affective advantages of entering the workforce in a recession. Administrative Science Quarterly, 58, 587 623.

Boswell, W. R., Gardner, R. G., \& Wang, J. (2017). Is retention necessarily a win? Outcomes of searching and staying. Journal of Vocational Behavior, 98, 163 172.

Cerit, Y. (2009). The effects of servant leadership behaviors of school principals on teachers' job satisfaction, Educational Management Administration Dr Leadership, 37 (5), $600-623$.

Chen F. C., Ku, E. C. S., Shyr Y. H., Chen F. H., \& Chou, S. S. (2009). Job demand, emotional awareness, and job satisfaction in internships: The indirect effect of social support, Social Behavior and Personality, 37 (10), 1429 - 1440.

Dennis, R. S., \& Bocarnea, M. (2005). Development of the servant leadership assessment instrument, Leadership \& Organization Development Journal, 26 (7/8), $600-615$.

Dennis, R. S., \& Winston, B. (2003). A factor analysis of Page and Wong's servant leadership instrument: from items to factors, Leadership \& Organization Development Journal, 24 (8), 455 - 459.

Dennis, R. S., Kinzler - Norheim, L., \& Bocarnea, M. (2010). Servant leadership theory. In Servant Leadership (pp. 169 - 179). Palgrave Macmillan UK.

Diestel, S., Wegge, J., \& Schmidt, K. (2014). The impact of social context on the relationships between individual job satisfaction and absenteeism: The roles of 
different foci of job satisfaction and work-unit absenteeism. Academy of Management Journal, 57 (2), 353-382.

Dutta, S., \& Khatri, P. (2017). Servant leadership and positive organizational behaviour: The road ahead to reduce employees' turnover intentions. On the Horizon, 25 (1), 60 - 82.

Farling, M. L., Stone, A. G., \& Winston, B. E. (1999). Servant leadership: Setting the stage for empirical research, Journal of Leadership Studies, 6 (1/2), 49 - 72.

Fonseca, L., Ramos, A., Rosa, Á. L., Braga, A. C., \& Sampaio, P. (2016). Stakeholders' satisfaction and sustainable success. International Journal of Industrial and Systems Engineering, 24 (2), 144 - 157.

Friday, S. S., \& Friday, E. (2003) Racioethnic perceptions of job characteristics and job satisfaction, Journal of Management Development, 22 (5), 426 - 442.

Gordon, V. (2011). Exploring the job satisfaction of municipal clerks, Review of Public Personnel Administration, 31 (2), 190 - 208.

Greenleaf, R. K. (1970). The servant as leader, In: The Greenleaf center for servant leadership, Westfield, New York.

Greenleaf, R. K. (1972). The servant as leader, In: The Greenleaf center for servant leadership, Westfield, New York.

Greenleaf, R. K. (1977). Servant Leadership: A journey into the nature of legitimate power and greatness, Paulist Press: New York.

Gunlu, E., Aksarayli, M. \& Percin, N. S. (2010). Job satisfaction and organizational commitment of hotel managers in Turkey. International Journal of Contemporary Hospitality Management, 22 (5), 693 - 717.

Ihm, J., Shumate, M., Bello - Bravo, J., Atouba, Y., Ba, N. M., Dabire - Binso, C. L., \& Pittendrigh, B. R. (2014). How Do Internal and External Stakeholders Perceive Organizational Field - Nets?. In Academy of Management Proceedings (Vol. 2014, No. 1, p. 11977). Academy of Management.

Irving, J. A., \& Longbotham, G. J. (2007). Team effectiveness and six essential servant leadership themes: A regression model based on items in the organizational leadership assessment. International Journal of Leadership Studies, 2 (2), 98 113.

Ishfaq A., Usman, A., \& Rana, S. L. (2011). Jobs satisfaction mediates relationship between facets of job and citizenship behavior: A study of female employees of banking sector of Pakistan, Information Management and Business Review, 3 (4), $228-234$.

Jaramillo, F., Grisaffe, D. B., Chonko, L. B., \& Roberts, J. A. (2009). Examining the impact of servant leadership on salesperson's turnover intention. Journal of Personal Selling \& Sales Management, 29 (4), 351 - 365.

Jha, S. (2014). Determinants of employee turnover intentions: A Review. Management Today, 9 (2), $01-13$.

Johnson, D. L. (2015). Leadership styles and their influence on organizational commitment and intentions to stay in an organization, (Unpublished Doctoral dissertation), Capella University. 
Joseph, E. E., \& Winston, E. B. (2005). A correlation of servant leadership, leader trust and organizational trust, Leadership \& Org. Development Journal, 26 (L), 6 - 22.

Judge, T. A., \& Locke, E. A. (1993). Effect of dysfunctional thought process on subjective well - being and job satisfaction, Journal of Applied Psychology, 78 (3), $475-490$.

Judge, T. A., Weiss, H. M., Kammeyer - Mueller, J. D., \& Hulin, C. L. (2017). Job attitudes, job satisfaction, and job affect: A century of continuity and of change. The Journal of Applied Psychology. 102 (3), 356 - 374.

Kalidass, A., \& Bahron A. (2015). The relationship between perceived supervisor support, perceived organizational support, organizational commitment and employee turnover intention, International Journal of Business Administration, 6 (5), 82 - 89.

Karsh, B., Booske, B. C., \& Saintfort, F. (2005). Job and organizational determinants of nursing home employee commitment, job satisfaction and intent to turnover, Ergonomics, 48 (10), 1260 - 1281.

Kool, M., \& Van Dierendonck, D. (2012). Servant leadership and commitment to change, the mediating role of justice and optimism. Journal of Organizational Change Management, 25 (3), 422 - 433.

Kostera, M., \& Pirson, M. (Eds.) (2017). Introduction to Dignity and Organization In: Dignity and the Organization, (pp. 1 - 9), Palgrave Macmillan UK.

Kreitner, R. \& Kinicki, A. (2012). Organizational behaviour (9th Ed.). New York: McGraw - Hill/Irwin

Lan, G., Okechuku, C., Zhang, H., \& Cao, J. (2013). Impact of job satisfaction and personal values on the work orientation of Chinese accounting practitioners, Journal of Business Ethics, 112, 627 - 640.

Laub, J. A. (1999). Assessing the servant organization development of the servant organizational leadership assessment (SOLA) instrument, (Unpublished Doctoral dissertation), Florida Atlantic University.

Liden, R. C., Wayne, S. J., Zhao, H., \& Henderson, D. (2008). Servant leadership: Development of a multidimensional measure and multi - level assessment, Leadership Quarterly, 19, 161 - 177.

Lok, P. \& Crawford, J. (2004). The effect of organizational culture and leadership style on job satisfaction and organizational commitment, Journal of Management Development, 23 (4), 321 - 338.

Metcalf, L., \& Benn, S. (2013). Leadership for sustainability: An evolution of leadership ability. Journal of Business Ethics, 112 (3), 369 - 384.

Mowday, R. T., Porter, L. W., \& Steers, R. M. (2013). Employee - organization linkages: The psychology of commitment, absenteeism, and turnover. Academic press, London, UK:

Northouse, P. G. (Eds.). (2010). Leadership: Theory and Practice, Fifth Edition, SAGE Publications Ltd. New York.

Page, D. \& Wong, T. P. (2000). A conceptual framework for measuring servant leadership. In S. Adjibolosoo (Ed.), The human factor in shaping the course of history and development, (pp. 69 - 110), Lanham, MD: University Press of America. 
Parris, D. L. \& Peachey, J. W. (2013). A systematic literature review of servant leadership theory in organizational contexts, Journal of Business Ethics, 113, 377 - 393.

Purvisa, R. L., Zagenczykb, T. J., \& McCrayc, G. E. (2015). What's in it for me? Using expectancy theory and climate to explain stakeholder participation, its direction and intensity, International Journal of Project Management, 33 (1), 3-14.

Randhawa, Ms. G. (2007). Relationship between job satisfaction and turnover intention, Indian Management Studies, 11, 149 - 159.

Reed, L. L., Vidaver - Cohen, D. \& Colwell, S. R. (2011). A new scale to measure executive servant leadership: Development, analysis, and implications for research, Journal of Business Ethics, 101, 415 - 434.

Robbins, S. P. \& Judge, T. A. (2012). Organizational behavior, 15th ed., Pearson, New York.

Russell, R. F. \& Stone, A. G. (2002). A Review of servant leadership attributes: Developing a practical model, Leadership and Organization Development Journal, $23(3), 145-157$.

Russell, R. F. (2001). The role of values in servant leadership, Leadership \& Organization Development Journal, 22 (2), 76 - 84.

Sam Gnanakkan, S. (2010). Mediating role of organizational commitment on HR practices and turnover intention among ICT professionals, Journal of Management Research, 10 (1), 39 - 61.

Scott, C. R., et al., (1999). The impacts of communication and multiple identifications on intent to leave, Management Communication Quarterly, 12, 400-435.

Sendjaya, S. \& Pekerti, A. (2010). Servant leadership as antecedent of trust in organizations. Leadership \& Organization Development Journal, 31 (7), 643 663.

Sendjaya, S. \& Sarros, C. J., (2002). Servant leadership: Its origin, development, and application in organizations, Journal of Leadership and Organization Studies, 9 (2), 57-64.

Sendjaya, S., Sarros, C. J. \& Santora, J. C. (2008). Defining and measuring servant leadership behavior in organizations, Journal of Management Studies, 45 (2), 401 $-424$.

Shipton, H., Sanders, K., Atkinson, C., \& Frenkel, S. (2016). Sense-giving in health care: the relationship between the HR roles of line managers and employee commitment. Human Resource Management Journal, 26 (1), 29 - 45.

Spears, L. C. (2010). Character and servant leadership: Ten characteristics of effective, caring leaders. The Journal of Virtues \& Leadership, 1 (1), 25 - 30.

Spears, L. C., \& Lawrence, M. (Eds.). (2002). Focus on leadership: Servant - leadership for the twenty - first century. John Wiley \& Sons.

Stone, G. A., Russell, R. F., \& Patterson, K. (2004). Transformational versus servant leadership: A difference in leader focus. Leadership \& Organization Development Journal, 25 (4), 349 - 361. 
Tarigan, V. \& Ariani, D. W. (2015). Empirical study relations job satisfaction, organizational commitment, and turnover intention. Advances in Management \& Applied Economics. 5 (2), 21 - 42.

Thompson, E. R., \& Phua, F. T. T. (2012). A brief index of affective job satisfaction. Group \& Organization Management. 37 (3), 275-307.

Turunç, Ö. \& Çelik, M. (2012). The moderating role of distributive justice on the both effect of job satisfaction on person-organization fit and supervisor trust on person-organization fit, Is - Guc, The Journal of Industrial Relations \& Human Resources, 14 (2), 57 - 78.

Vinod, S. \& Sudhakar, B. (2011). Servant leadership: A unique art of leadership!, interdisciplinary Journal of Contemporary Research in Business, 2 (11), 456 467.

Vondey, M. (2010). The relationships among servant leadership, organizational citizenship behavior, person - organization fit and organizational identification, International Journal of Leadership Studies, 6 (L), 3 - 27.

Walumbwa, F. O., Hartnell, C. A., \& Oke, A. (2010). Servant leadership, procedural justice climate, service climate, employee attitudes, and organizational citizenship behavior: a cross - level investigation. Journal of Applied Psychology, 95 (3), 517.

Wang, J. H., Tsai, K. C., Lei, L. J. R., \& Lai, S. K. (2016). Relationships among job satisfaction, organizational commitment, and turnover intention: evidence from the gambling industry in Macau. Business and Management Studies, 2(1), 104 110.

Wong, P. T., Davey, D., \& Church, F. B. (2007). Best practices in servant leadership. Servant Leadership Research Roundtable, School of Global Leadership and Entrepreneurship, Regent University.

Yamane, T. (2001). Temel Örnekleme Yöntemleri, (E. Alptekin, \& Diğerleri, Çev.), İstanbul: Lİteratür Yayıncılık.

Yang, X. \& Wang, W. (2013). Exploring the of job satisfaction of civil servants in Beijing, China, Public Personnel Management, 42 (4), 566 - 587.

Yoshida, D. T., Sendjaya, S., Hirst, G., \& Cooper, B. (2014). Does servant leadership foster creativity and innovation? A multi - level mediation study of identification and prototypically. Journal of Business Research, 67 (7), 1395 - 1404. 